\title{
On the Polarity of the Electric Charges on Snow Crystals of the Various Shapes*
}

\author{
By Katsuhiro Kikuchi \\ Department of Geophysics, Hokkaido University, Sapporo \\ (Manuscript received 14 May 1973, in revised form 18 Ju!y 1973)
}

\begin{abstract}
Some observations in the field of cloud physics and atmospheric electricity were carried out when the author was a member of the wintering party of the 9th Japanese Antarctic Research Expedition at Syowa Station, Antarctica throughout the whole year from February 1968 to January 1969. Especially, a simultaneous observation of electric charges on natural falling snow crystals, the shapes of snow crystals and electric field strength were selected from a view point of importance and interest of the charge generation in clouds.

As a result, a very interesting phenomenon was found in which the electric polarity of snow crystals of dendrite, sector and plate was negative and the polarity of snow crystals of column, combination of bullets and side plane was positive. Taking into account that the temperature range of the growth of dendrite, sector and plate is roughly between $-10^{\circ}$ and $-20^{\circ} \mathrm{C}$ and that of the other three shapes of snow crystals are between $-20^{\circ}$ and $-35^{\circ} \mathrm{C}$, it would be appropriate to assume a positive polarity of a thundercloud and other electrified clouds with solid precipitation particles. In other words, it may be considered that negative and positive charge centers in the cloud volume are located around the $-15^{\circ} \mathrm{C}$ level and the $-25^{\circ} \mathrm{C}$ to $-35^{\circ} \mathrm{C}$ level, respectively. These temperature ranges coincide with Takahashi's observation (1965) using an electric charge sonde, in which he reported that positive charged particles were observed at a temperature range between $-18^{\circ}$ and $-39^{\circ} \mathrm{C}$ and negative charged particles were present at a range between $0^{\circ}$ and $-18^{\circ} \mathrm{C}$.
\end{abstract}

\section{Introduction}

It is generally known that the polarity of the electrical charges on rain drops is positive and that the polarity of the electrical charges on snow crystals is negative. And it is also known that at times there are an "inverse-relation" and "mirror image relation" between the polarity of the electrical charges on precipitation elements and the polarity of the atmospheric electric field strength (Magono and Orikasa (1960, 1961, 1966), Orikasa (1962), Chalmers (1965), Owolabi (1970)). A few observations of electric charge to the sign of snow particles have been carried out till the present (Nakaya and Terada (1934), Magono et al. (1957), Isono $e_{t}^{t}$ al. (1966)). However, they are limited in sample number and short period of the observations. Furthermore, no explanation

* This work was done when the author was a member of Meteorological Research Section, Wintering Party, the 9 th Japanese Antarctic Research Expedition (1968-1969). as to the shapes of snow crystals carrying negative charges has been given so far. On the other hand, it is well known that the habit of the shapes of snow crystals is decided by both temperature and supersaturation with respect to the ice surface (Nakaya (1954), Hallett and Mason (1958), Kobayashi (1961)).

Recently, Odencrantz and Buecher (1967) examined the temperature-dependency of the polarity of electrical charges on ice crystals by seeding in laboratory experiments. As a result, they concluded that ice crystals in a temperature range between $-3^{\circ}$ and $-8^{\circ} \mathrm{C}$ acquired positive charges and in a range between $-8^{\circ}$ and $-25^{\circ} \mathrm{C}$ acquired negative charges. But in the following paper, Odencrantz (1968) examined the modification of habit and charge of ice crystals growing in contaminated vapor in an experimental cold box. And he arrived at the conclusion that the effect of contaminated vapor was larger than that of the temperature with special regard to the charge of ice crystals. 
The author carried out some observations in the field of cloud physics and atmospheric electricity when he was a member of the wintering party of the 9 th Japanese Antarctic Research Expedition at Syowa Station $\left(69^{\circ} 00^{\prime} \mathrm{S}, 39^{\circ} 35^{\prime} \mathrm{E}\right)$ throughout the whole year from February 1968 to January 1969. The observations of electrical charges on the natural falling snow crystals and blowing and drifting snow particles, the shapes of snow crystals (Kikuchi, 1969, 1970a) and electric field strength (Kikuchi, 1970b) were selected from a view point of importance and interest of the charge generation mechanism in clouds.

\section{Observation site and equipments}

Syowa Station is located on East Ongul Island. The distance between East Ongul Island and the Antarctic Continent is approximately $4 \mathrm{~km}$. In the summer season, from the end of December to the beginning of February, the Ongul Strait remained open but in the winter season, permanent fast ice and icebergs covered the Lützow-Holm Bay to a $100 \mathrm{~km}$ distance from the coast.

The observation of the shapes of snow crystals was done by microscopic photography and the replica solution method and the charges on snow crystals were measured by making current flow through a high resistance tube for each crystal (Magono and Orikasa, 1960). The measuring limit of the electrometer was $2 \times 10^{-4}$ esu. At the

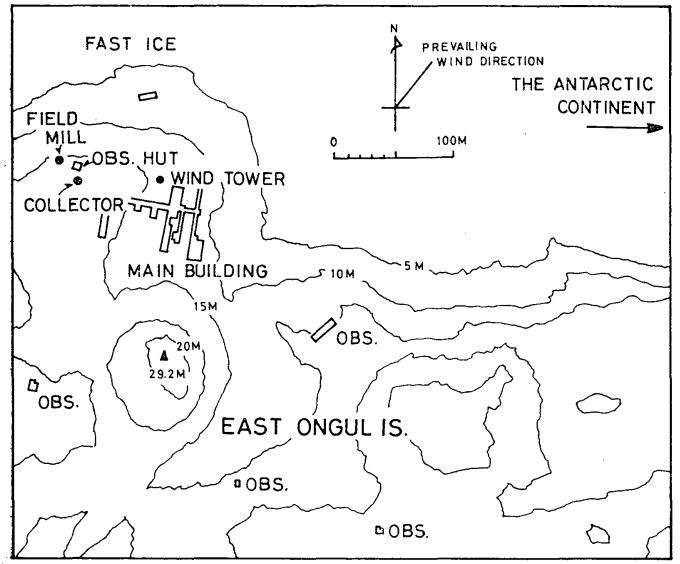

Fig. 1. Map around Syowa Station (Observation hut, charge meter collector, Field Mill and wind tower are seen on upper left side) same time, a "Field Mill" type of electrometer (Gathman and Anderson, 1965) was used for the observation of the atmospheric potential gradient. A collector with a pre-amplifier for the measurement of the charges on snow crystals was set about $5 \mathrm{~m}$ apart from the observation hut and was moved to different positions depending on the wind direction (Fig. 1). The "Field Mill" was set up about $20 \mathrm{~m}$ apart from the observation hut parallel to the direction of the prevailing wind. The recorder of the "Field Mill" was operated at $60 \mathrm{~mm} / \mathrm{hr}$ to $300 \mathrm{~mm} / \mathrm{hr}$ of chart speed in all weather. On the other hand, the recorder of the charge meter was run at $120 \mathrm{~mm} /$ min of chart speed during precipitation time alone. The microscopic photography and replica solution method were carried out at approximately 10 minute intervals.

\section{Observational results}

Fig. 2 shows a typical example of negative charged snow crystals. The axis of the ordinate on the left hand side show the number concentration of snow crystals, $\left(N_{+}\right)$and $\left(N_{-}\right)$, per $\mathrm{cm}^{2} \cdot \mathrm{min}$ and the right hand side is the mean charge of the snow crystals, $\left(\bar{Q}_{+}\right)$and $\left(\widehat{Q}_{-}\right)$, esu and the abscissa shows the local mean time. The upper side shows positive polarity and lower side shows negative. Thus the solid lines, connected dots, indicate the time change of the number concentration of falling snow crystals carrying positive and negative charges and the white circles indicate the average charges on the snow crystals of which the number concentrations are shown by solid lines. For practical purposes, although a $30 \mathrm{~cm}^{2}$ collector plate for the preamplifier was used, the figure of 1 on the left ordinate indicates roughly 30 snow crystals per minute. In this example, the shape of snow crystals was dendrite. The surface air temperature and wind direction and velocity (knots) are as indicated for each hour. Fig. 3 shows the same example. But, in this case, the shapes of snow crystals were plates and a rimed radiating assemblage of dendrites. One of microscopic photographs taken at 1550 is shown in Fig. 4.

As was seen in Fig. 3, the negative charged snow crystals stood high above the positive ones throughout the observation period. On the other hand, the potential gradient showed positive and the maximum value throughout the same period was about 4 times of the undisturbed one. Fig. 5 


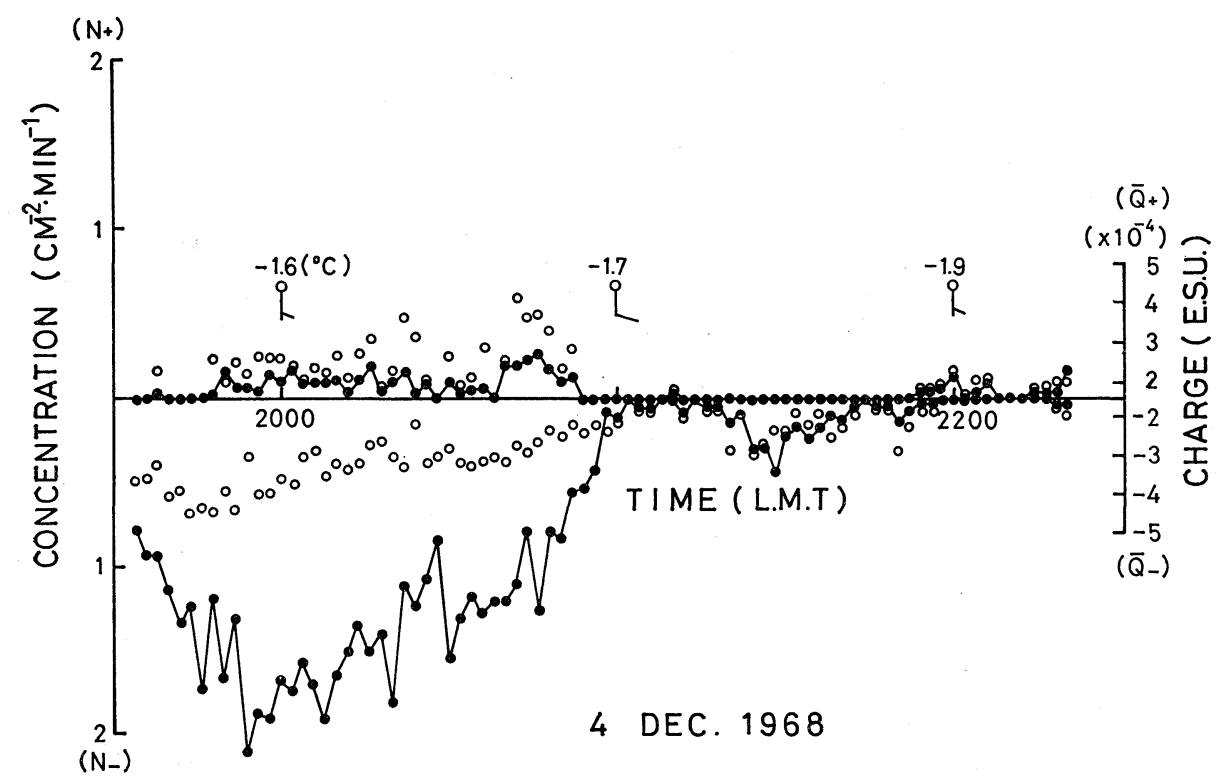

Fig. 2. Time variation of the number concentration and the average charge of falling snow crystals of "dendrite" type at Syowa Station on 4 December, 1968.

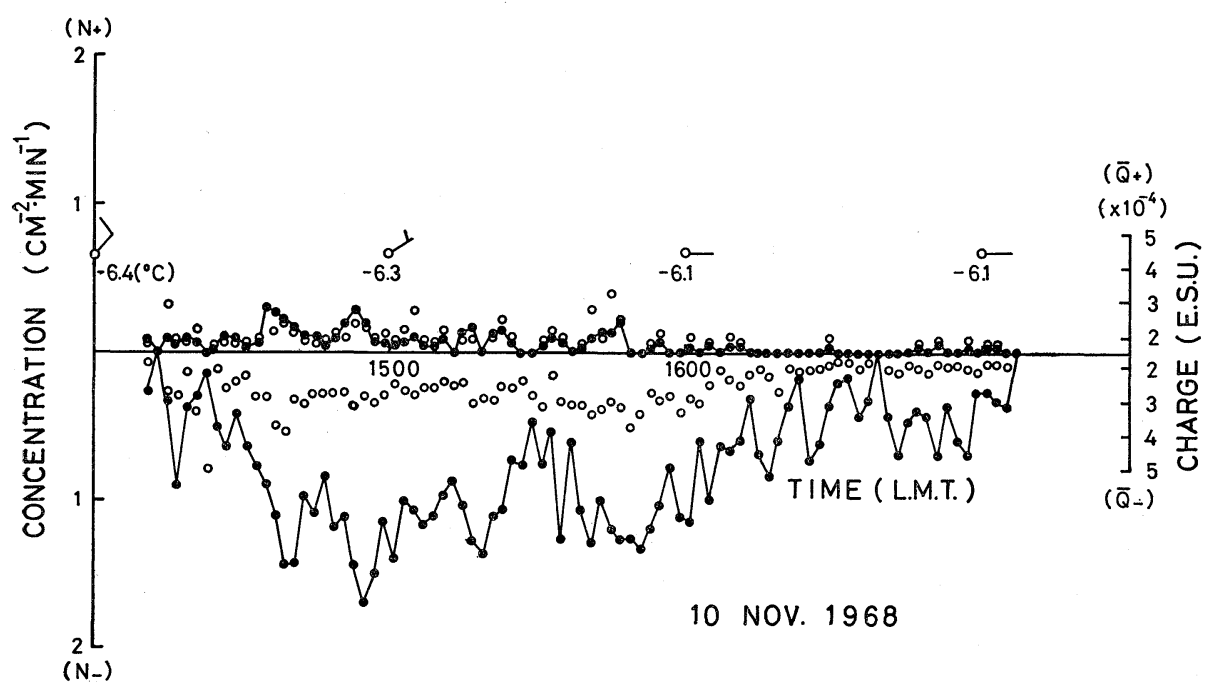

Fig. 3. Time variation of the number concentration and the average charge of falling snow crystals of "plate" and "rimed radiating assemblage of dendrites" at Syowa Station on 10 November 1968. 


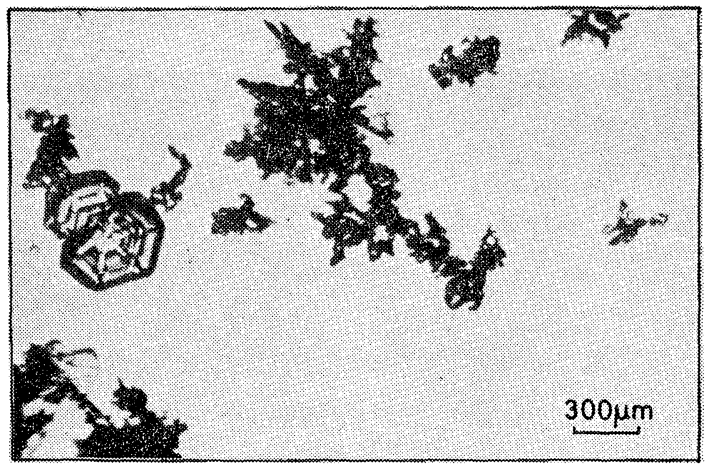

Fig. 4. A microscopic photograph of snow crystals of "plate" and "rimed radiating assemblage of dendrites".

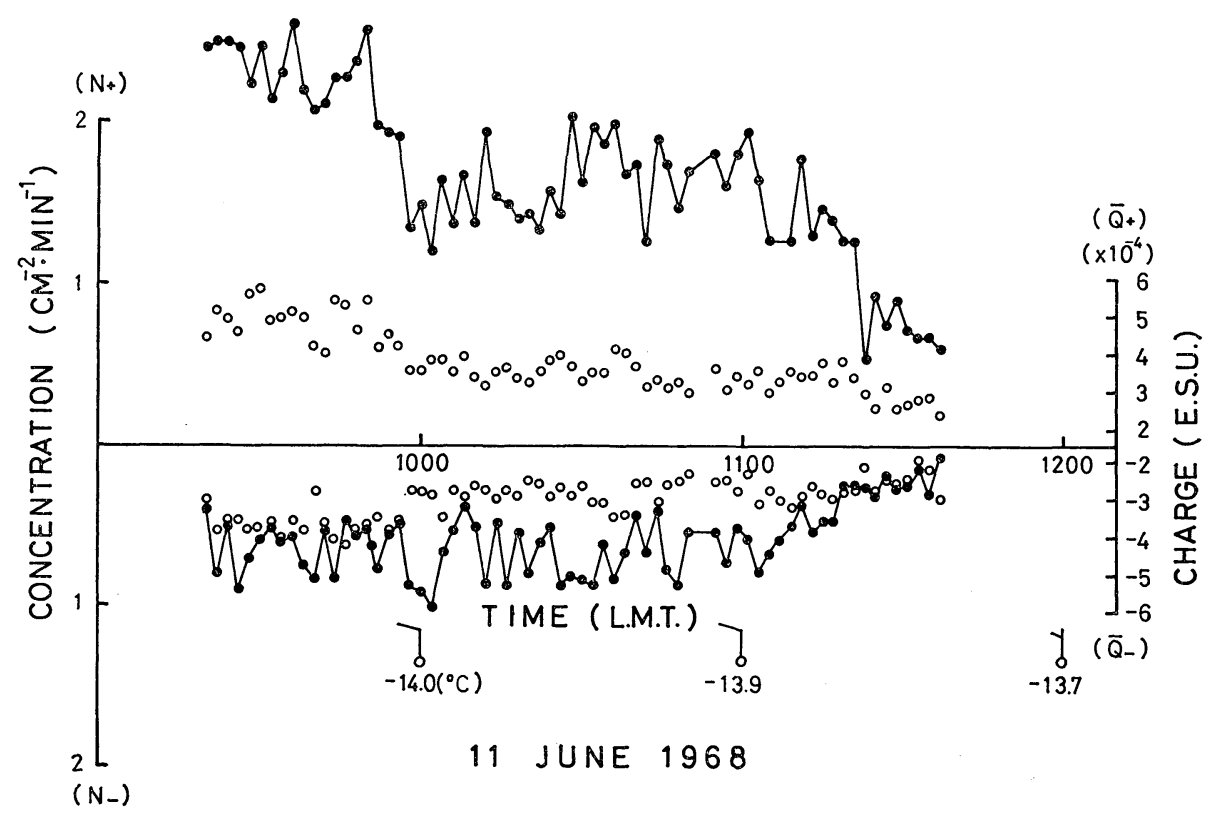

Fig. 5. Time variation of the number concentration and the average charge of falling snow crystals of "side plane" and "column" at Syowa Station on 11 June 1968.

shows a different example, that is to say, the polarity of the charges on snow crystals is more positive than negative. And the shapes of snow crystals were side planes and columns as seen in Fig. 6. One of peculiar shapes of snow crystals reported by Kikuchi $(1969,1970 a)$ is seen in the figure by an arrow. Fig. 7 is another example of the same. The shapes of snow crystals in this case were a combination of bullets, columns and side planes. The wind condition was very calm and a surface air temperature was relatively low. And the potential gradient was almost constant and less than the undisturbed value. This means the potential gradient is directed to the negative. Throughout the whole year of wintering, the so-called no wave patterns of the potential gradient were observed at Syowa Station. Furthermore, negative potential gradient were not observed except under conditions of very violent snow storms (kikuchi, 1970b). One 


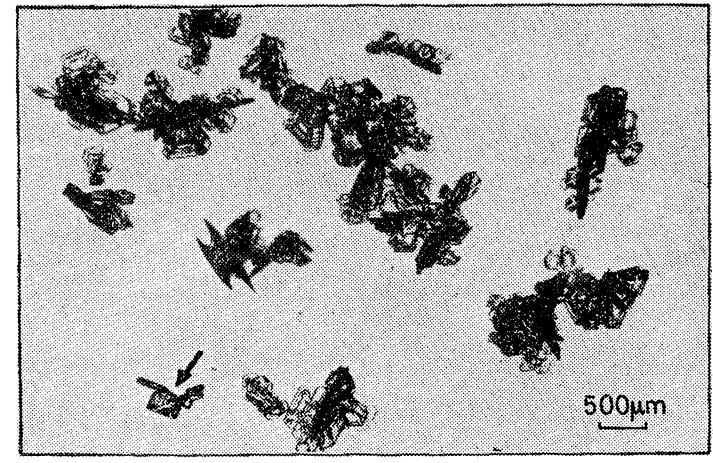

Fig. 6. A microscopic photograph of snow crystals of "side plane" type. Arrow indicates one of the peculiar shapes of the crystals.

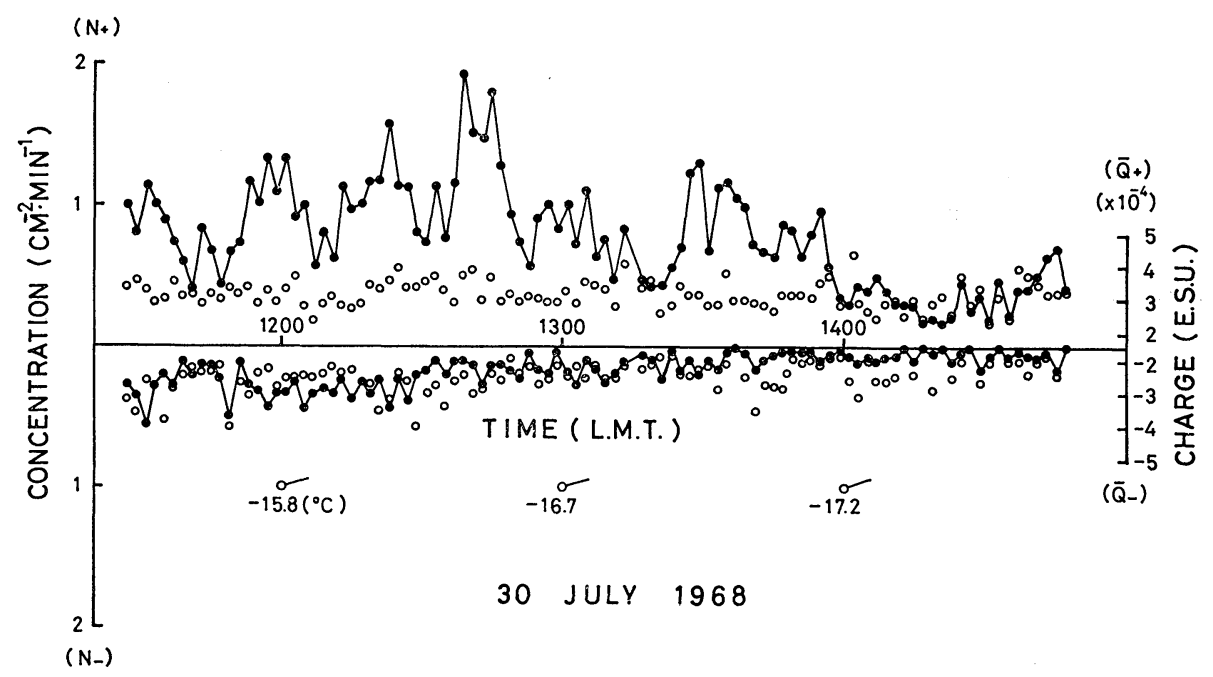

Fig. 7. Time variation of the number concentration and the average charge of falling snow crystals of "combination of bullets", "column" and "side plane" at Syowa Station on 30 July 1968.

of the reasons may be attributed to the fact that no rain was seen during the observation period. Another reason may be that no cellular cumulus clouds of a mature stage with precipitations were present.

During the wintering period at Syowa Station, a precipitation of frozen cloud particles was encountered (Kikuchi, 1972). It was considered quite important to investigate the electric polarity of the frozen cloud particles, because it involves the problem of charge generation mechanism of ice crystals and snow crystals. In this case, of course, the charging involves the process of condensation to freezing and not the process of sublimation. Fig. 8 shows one of the examples of frozen cloud particles. As far as this example is concerned, the particles of negative polarity exceed that of positive. Especially, it was clear that the negative polarity predominate during the period between 1700 and 1800 LMT. Although it was found that the magnitude of the charge increased with the increment of the number concentration of the precipitation particles, it should be realized that the magnitude of the 


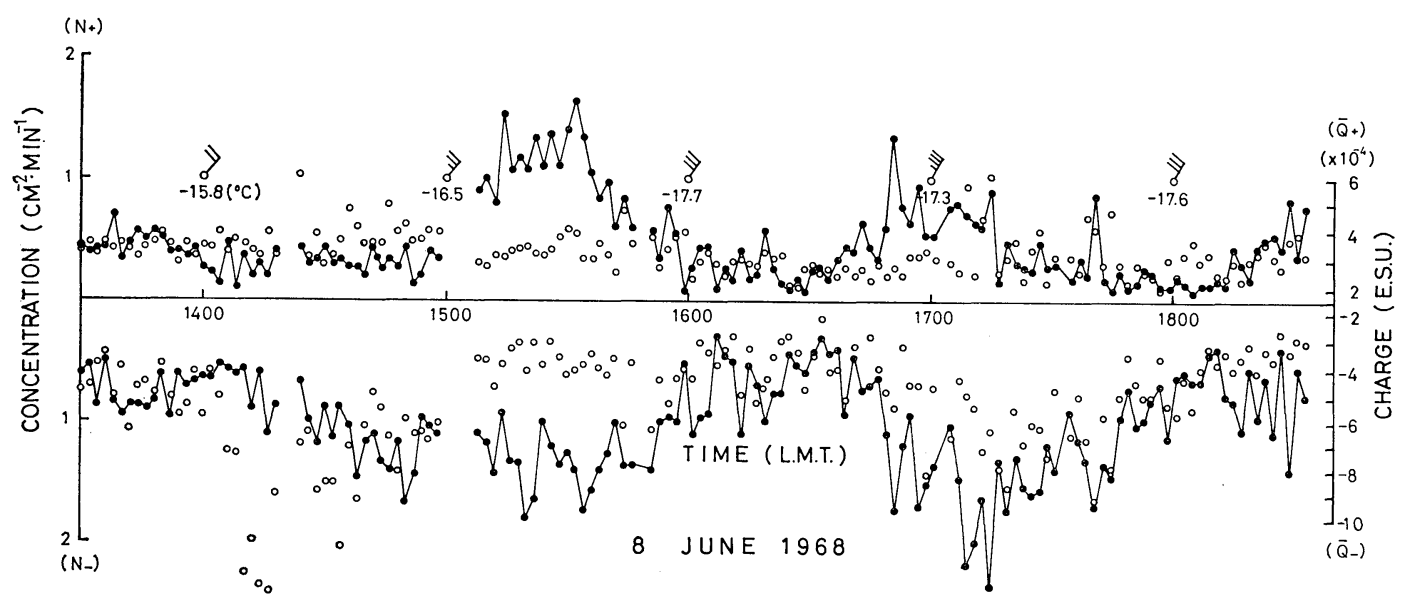

Fig. 8. Time variation of the number concentration and the average charge of precipitation of "sintered frozen cloud particles" at Syowa Station on 8 June 1968.

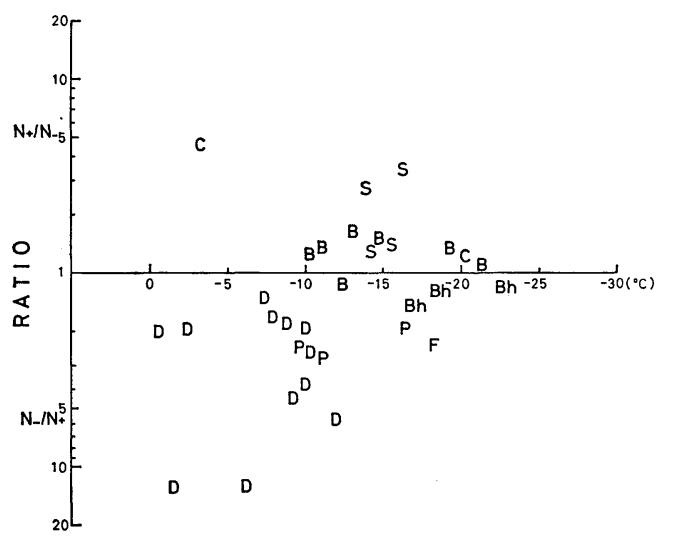

Fig. 9. The relation between the number ratio and the shape of snow crystals under surface air temperature conditions. (B: bullet and combination of bullets, C: column, D: dendrite, $F$ : frozen cloud particles, $\mathrm{P}$ : plate, $\mathrm{S}$ : side plane, and Bh: hollow bullet).

negative charge of the frozen cloud particles is greater than that of the above described examples. One of the reasons is that the wind velocity in this case is greater than that of the previous cases. Hence it is considered that the charging in this case involves the processes of condensation to freezing and some kind of friction and fragmentation.

\section{Considerations and conclusions}

Fig. 9 shows the summary of the observational results described previously. The ordinate shows the snow crystal number ratio, $N_{+} / N_{-}$and $N_{-} / N_{+}$, for each falling snow. $N_{+}$and $N_{-}$ denote the total numbers of positively and negatively charged snow crystals. The total numbers of snow crystals for each falling snow used in this figure are $500 \sim 20,000$ crystals. The abscissa shows the surface air temperature at the observation site. It is clear in this figure that the shapes of negatively charged snow crystals are restricted to "dendrite" (D), "plate" (P) and "frozen cloud particle" (F). On the other hand, "column" (C), "bullet" (B) and "side plane" (S) are charged positively. However, the shape of "hollow bullet" (Bh) showed a slight difference, namely, the ratio is near unity. Taking into account the fact that the temperature range of the growth of the shapes of "dendrite", "sector" and "plate" is roughly between $-10^{\circ}$ and $-20^{\circ} \mathrm{C}$ and that the other three shapes of snow crystals, namely "column", "combination of bullets" and "side plane" are between $-20^{\circ}$ and $-35^{\circ} \mathrm{C}$ (Magono, Kikuchi and Yamami, 1971), it would be appropriate to assume a positive polarity of a thundercloud and other electrified clouds. In other words, it may be considered that negative and positive charge centers in the cloud volume are located around the $-15^{\circ} \mathrm{C}$ level and the $-25^{\circ} \mathrm{C}$ to $-30^{\circ} \mathrm{C}$ level, respectively. Recently Takahashi (1965) observed negative charged particles at a temperature range between $0^{\circ}$ and $-18^{\circ} \mathrm{C}$ and positive charged particles at a range between $-25^{\circ}$ and $-39^{\circ} \mathrm{C}$ by using an electric charge sonde. These temperature ranges 


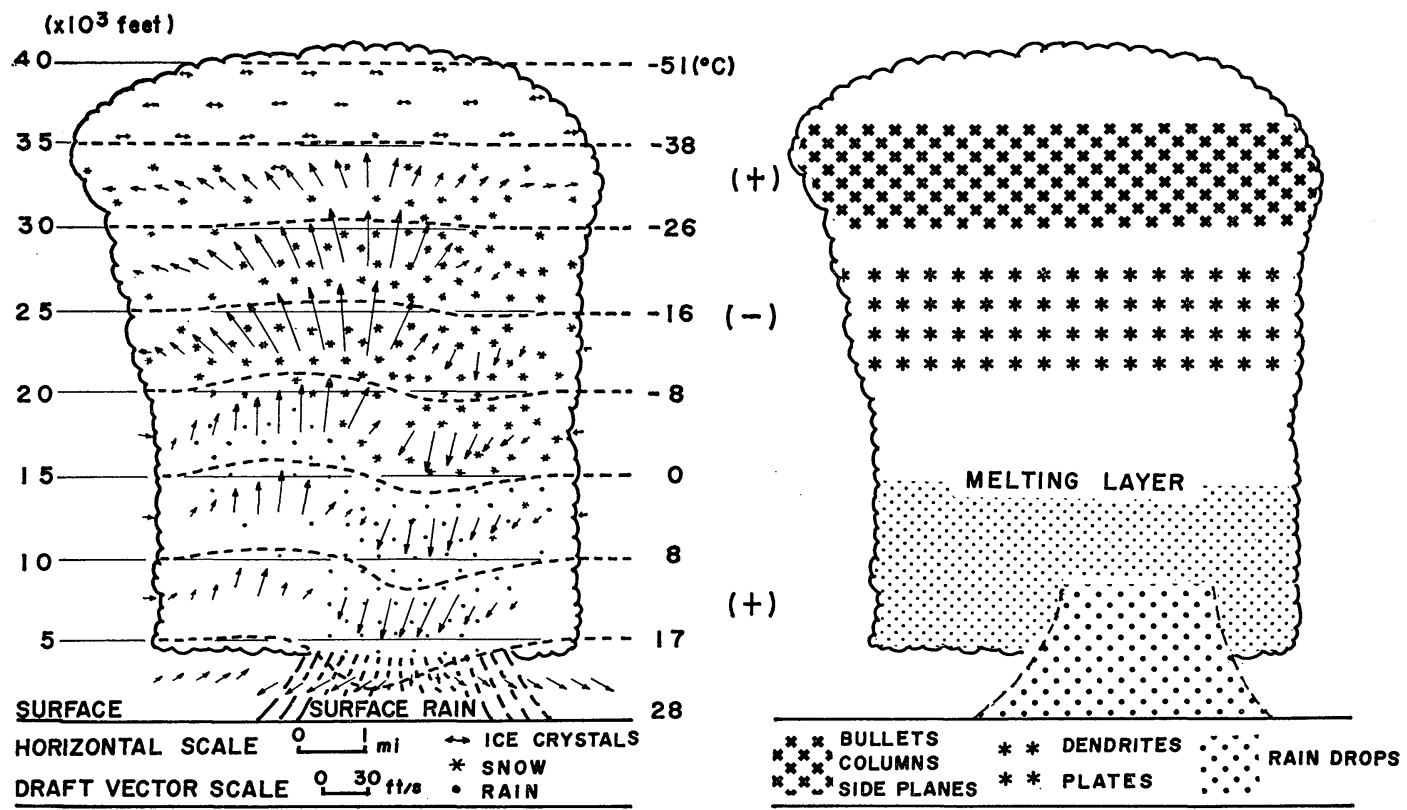

Fig. 10. A model of thunderclouds of the mature stage added to the conditions of the polarity of charges on the shapes of snow crystals. (Original figure on the left hand side is after Byers and Braham (1949)).

coincide with the growth range of the described shapes of snow crystals. Magono and his co-worker (1969) obtained similar results using their electric charge sonde and alti-electrograph.

As a result, to introduce the relationship between the polarity of charge and the growth range of snow crystals in the model of a mature stage of thundercloud introduced by Byers and Braham (1949), Fig. 10 is presented. In this model on the left hand side in this figure, however, they do not describe the shapes of snow crystals and the polarity of charges on snow crystals. Here if we give consideration to the shapes of snow crystals and the temperature distributions in the cloud bases on the growth range of snow crystals, it becomes as the author has attempted to show in the right hand side in this figure. In other words, around the $-30^{\circ} \mathrm{C}$ layer, positively charged snow crystals, namely, columns, combination of bullets and side planes are concentrated, and around the $-15^{\circ} \mathrm{C}$ layer, negatively charged snow crystals, namely, dendrites and plates are concentrated. If a steady state is reached and holds in the clouds for some time, a positive polarity in the cloud will build up qualitatively considering the shapes of snow crystals. Although the polarity of charges on precipitation particles depends on the impurity, for instance, as shown in the results of Odencrantz (1968), it is considered that the statistical results described previously are important because of the following facts, namely, it was in the Antarctica, it was natural falling snow, and there were no wave patterns of atmospheric electric field during these snowfalls. The positively charged region below a meiting layer may well be explained by the melting effect (Dinger and Gunn; 1946, Magono and Kikuchi; 1963, 1965 and Kikuchi; 1965), namely a bursting of air bubbles on the surface of precipitation elements.

Although the reason for the difference of the electric polarity arising from the shapes of snow crystals is not clear at this time, this finding seems to be of considerable importance in the discussion of charge generation and separation in thunderclouds and other electrified clouds with solid precipitation particles.

\section{Acknowledgements}

The author expresses his sincere gratitude $\mathrm{Mr}$. Murayama, the leader of the 9 th Japanese Antarctic Research Expedition and to Mr. T. Sekino, one of the engineers of the expedition 
for their kind cooperation in the field of the logistics at Syowa Station. The expense of this study was defrayed by the Antarctic Office of the Educational Ministry of Japan.

\section{References}

Byers, H.R. and R.R., Braham, Jr.. 1949: The Thunderstorm. U.S. Bureau, $287 \mathrm{pp}, 23$.

Chalmers, J.A., 1965: The relation between precipitation current and potential gradient. J. Atmos. Terr. Phys., 27, 899-905.

Dinger, J.E. and R. Gunn, 1946: Electrical effects associated with a change of state of water. Terr. Magn. Atmos. Elect., 51, 477-494.

Gathman, S.G. and R.V. Anderson, 1965: Improved field meter for electrostatic measurements. Rev. Sci. Instr., 36, 1490-1493.

Hallett, J. and B.J. Mason, 1958: The influence of temperature and supersaturation on the habit of ice crystals grown from the vapour. Proc. $R$. Soc., A 247, 440-453.

Isono, K., M. Komabayasi and T. Takahashi, 1966: A physical study of solid precipitation from convective clouds over the sea: Part III. J. Meteor. Soc. Japan, 44, 227-233.

Kikuchi, K., 1965: On the positive electrification of snow crystals in the process of their melting (III), (IV). J. Meteor. Soc. Japan, 43, 343-350, 351-357.

— 1969: Unknown and peculiar shapes of snow crystals observed at Syowa Station, Antarctica. J. Fac. Sci., Hokkaido Univ., Ser. VII, 3, 99-116.

, 1970a: Peculiar shapes of solid precipitation observed at Syowa Station, Antarctica. $J$. Meteor. Soc. Japan, 48, 243-249.

1970b: Observations of the atmospheric electric field at Syowa Station, Antarctica. $J$. Meteor. Soc. Japan, 48, 452-460.

, 1972: Sintering phenomenon of frozen cloud particles observed at Syowa Station, Antarctica. J. Meteor. Soc. Japan, 50, 131-135.

Kobayashi, T., 1961: The growth of snow crystals at low supersaturations. Phil. Mag., 6, 1363-1370.

Magono, C., T. Endoh, T. Shigeno, T. Iwabuchi and C.W. Lee, 1969: Electric nature of the snow clouds (Part I). Paper presented at the meeting of the Meteor. Soc. Japan held in Fukuoka.

Magono, C. and K. Kikuchi, 1963: On the positive electrification of snow crystals in the process of their melting. J. Meteor. Soc. Japan, 41, 270-277. 1965: On the positive electrification of snow crystals in the process of their melting, (II). J. Meteor. Soc. Japan, 43, $331-342$.

Magono, C., K. Kikuchi and N. Yamami, 1971: On the meteorological conditions for the growth of snow crystals in colder temperature regions, as revealed by radiosonde data in the Antarctica. J. Meteor. Soc. Japan, 49, 179-183.

and K. Orikasa, 1960: On the surface electric field during rainfall. J. Meteor. Soc. Japan, 38, 182-194.

electric field caused by the space charge of charged raindrops. J. Meteor. Soc. Japan, 39, 1-11.

1966: On the disturbance of surface electric field caused by snowfall. $J$. Meteor. Soc. Japan, 44, 260-279. The charge on precipitation elements and surface electric potential gradient. J. Fac. Sci., Hokkaido Univ., 1, 7-20.

Nakaya, U., 1954. Snow Crystals, natural and artificial. Harvard Univ. Press, 510 pp. 249.

- and T. Terada, 1934: On the electrical nature of snow particles. J. Fac. Sci., Hokkaido Univ., Ser. II, 1, 181-190.

Odencrantz, F.K., 1968: Modification of habit and charge of ice crystals by vapor contamination. J. Atmos. Sci., 25, 337-338. and R.W. Buecher, 1967: Temperature dependence of the polarity of electrical charges on ice crystals. Science, 158, 256-257.

Orikasa, K., 1962: On the disturbance of the surface electric field caused by rain and snowfall (in Japanese). Geophys. Bull., Hokkaido Univ., 9, $123-160$

Owolabi, I.E., 1970: The inverse-relation and the mirror-image effect in precipitation. J. Atmos. Terr. Phys., 32, 1205-1213.

Takahashi, T., 1965: Measurement of electric charge in thundercloud by means of radiosonde. $J$. Meteor. Soc. Japan, 43, 206-217. 


\title{
雪結晶の結晶形と電荷符号についで
}

\author{
菊地 勝 弘 \\ 北海道大学理学部地球物理学教室
}

1968年 2 月から1969年 1 月までの 1 年間, 南極昭和基地での越冬観測期間中に種々の雲物理, 大気電気に関する観 測を行なったが, 特に降水粒子の電荷発生機構の観点から雪結晶の電荷と結晶形の関係をみるために多くの降雪の電 荷の測定と同時に顕微鏡, レプリカによる結晶形の観測が行なわれた，その結果，樹枝状六花，角板は負の電荷を有 するものが多く, 角柱, 砲弾集合, 側面結晶は正の電荷を有するものが多かった。これらの結果は観測場所が清浄な 南極であること, 大きな雪片がほとんど降らないこと, 天然の降雪でしかも各降雪毎の測定個数が非常に多いこと, 大気電場の変動にいわゆる wave pattern がなかったことなどから信頼の䑙けるるのである. 更に各結晶形の成長す る温度範围, すなわち樹枝状六花, 角枝は $-10^{\circ} \mathrm{C} \sim-20^{\circ} \mathrm{C}$, 角柱, 砲弾集合, 側面結晶は $-20^{\circ} \mathrm{C} \sim-35^{\circ} \mathrm{C}$, を考 慮することによって雷雪等の正極性の電荷分布を定性的に説明することができ，これからの電荷発生，分離を論ずる 際には結晶形も考慮する必要があると考觉られる。

* 第 9 次日本南極地域観测隊越冬隊員（気像研究部門担当）の時になされたものである. 